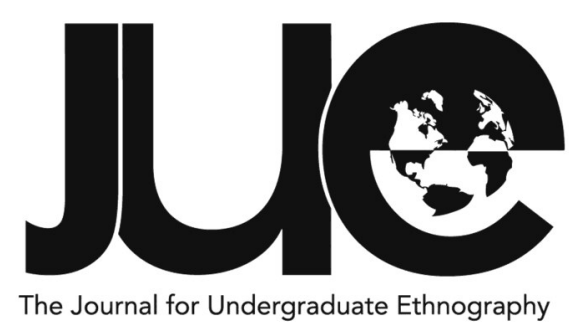

\title{
Why We Love It Here: Exploration of Affection and Attachment in a Brazilian Urban Periphery
}

Sue-Yeon Ryu

Ohio University, sr495714@ohio.edu

\section{ABSTRACT}

This research interprets the marginalized neighborhood of Serrinha as a place in the city of Florianópolis, Brazil, by examining the relations between the physical neighborhood and internal social networks. I use concepts from the anthropology of materiality and an interdisciplinary understanding of place attachment to examine how the social and physical dimensions of place coalesce within Serrinha. I employ data from eight weeks of ethnographic research and Scannell and Gifford's tripartite model of place attachment to frame the everyday experiences and affects of Serrinha residents, especially to illustrate Serrinha outside of the typical stereotypes of favelas. In doing so, the study analyzes the symbolic significance of brick as the material of choice for Serrinha's self-built houses and asserts that the brick is a metaphor for local and global relationships. Ultimately, this research argues that autoconstruction of the house with brick constitutes a significant social and emotional process of attachment in Serrinha.

Keywords: material analysis; place attachment; periphery; identity; autoconstruction 
"We have an affection for this place."

-Santijunior

W hile Lourenço and I split a beer at the small wooden counter at Bar Rotta, a tiny room converted into a bar on the corner of Serrinha's main road, its owner, Rafael Junior, sat across from us and proudly showed us a video on his phone that he had taken at his house earlier. He had been standing atop the half-built floor that would soon be his home (the third floor of the house), horizontally videotaping the view he would have from his window. It was a $180^{\circ}$ view of the city of Florianópolis, from the northwestern to the southwestern coast of the island. Rafael Junior considers his house to be the greatest location in Serrinha and stated that even if a buyer were to offer US\$3M for it, a reasonable price for which a house with a similar view may sell for in the United States, he would never sell, even though the average price of a Serrinha home is around US\$2,200 (Infosolo 2006 as cited in Lonardoni 2007, 56). Because once he finishes constructing the floor, he will finally be able to have his own space away from his mother and sister, with whom he shares the house. His living there is indefinite; he refuses to move to the nicer neighborhood on the North of the island where his girlfriend lives, especially due to the connection he has with his house and family. In the future, Rafael Junior is committed to raising his family in Serrinha.

For this article, I draw heavily from the concept of place attachment to understand the favela of Serrinha and how social networks and systems are linked to the physicality of the favela. (Favela is a Brazilian term that is best translated to 'slum' in English; I further explain the term in the next section.) In addition, I borrow notions from the anthropology of materiality-a subfield conceptualizing the reciprocal interactions between people and material-to explore brick as a metaphor for social relations. Building on this approach, I argue that the brick as a material comprises social meaning, and I assert that the housenot the neighborhood-is the significant range of attachment in Serrinha. This is especially true because Serrinha homes are autoconstructed, which is the foundation for many favela neighborhoods (Caldeira 2012, 387) and one of the key differences between homes in favela and non-favela neighborhoods. BrazilianAmerican anthropologist Teresa Caldeira (2012) explains that "an autoconstructed house is always something in the making...improved and extended step by step over many decades, depending on the family resources" (387). In other words, residents use their own resources to gather materials, space, and build their home. This is not a one-and-done process; there is generally always a sense of change or improvement as residents construct more rooms, swap out materials, or remodel as their financial or social positions evolve. This means residents have self-built their homes over time and in the process have integrated social relationships of attachment and kinship into the physical house. To demonstrate the interactions between autoconstruction, place attachment, and material in Serrinha, I first provide conceptual contexts for urban spaces and favelas before introducing my ethnographic findings. My findings suggest that in Serrinha, residents are deeply connected to and identified by their physical homes, particularly because the house symbolizes the process of building a family, tight social network, and identity. The choice of material for the house is also salient, as the difference between brick and wood Serrinha houses points towards broader social exclusions that follow lines of racial and class discrimination.

\section{Conceptual Framework}

\section{The Urban Favela}

Uneven urban development has divided many city geographies into the "center" and the "periphery." The term center refers to both a literal geographic location and to a centralization of wealth and power regarded as legitimate and formal. Formal in this sense signifies a lifestyle in which there is "regularity of its order, a predictable rhythm and sense of control that we often take for granted" (Hann and Hart 2011, 114). In contrast, periphery refers to the informal spatial fringes surrounding the center and their corresponding exclusion from wealth, power, and regularity. 
The informality of urban peripheries in the Global South has historically referred to the illegal and thus, undocumented, construction of self-built houses wherever there is physical space (see Figure 1), complicating land ownership and related issues (Perlman 2010, 296). Where these types of houses congregate become areas of insecure housing with a general lack of formal infrastructure and difficult access to social resources (Pequeno 2008). Around the world these areas are studied as slums, but specifically known in Brazil as favelas.

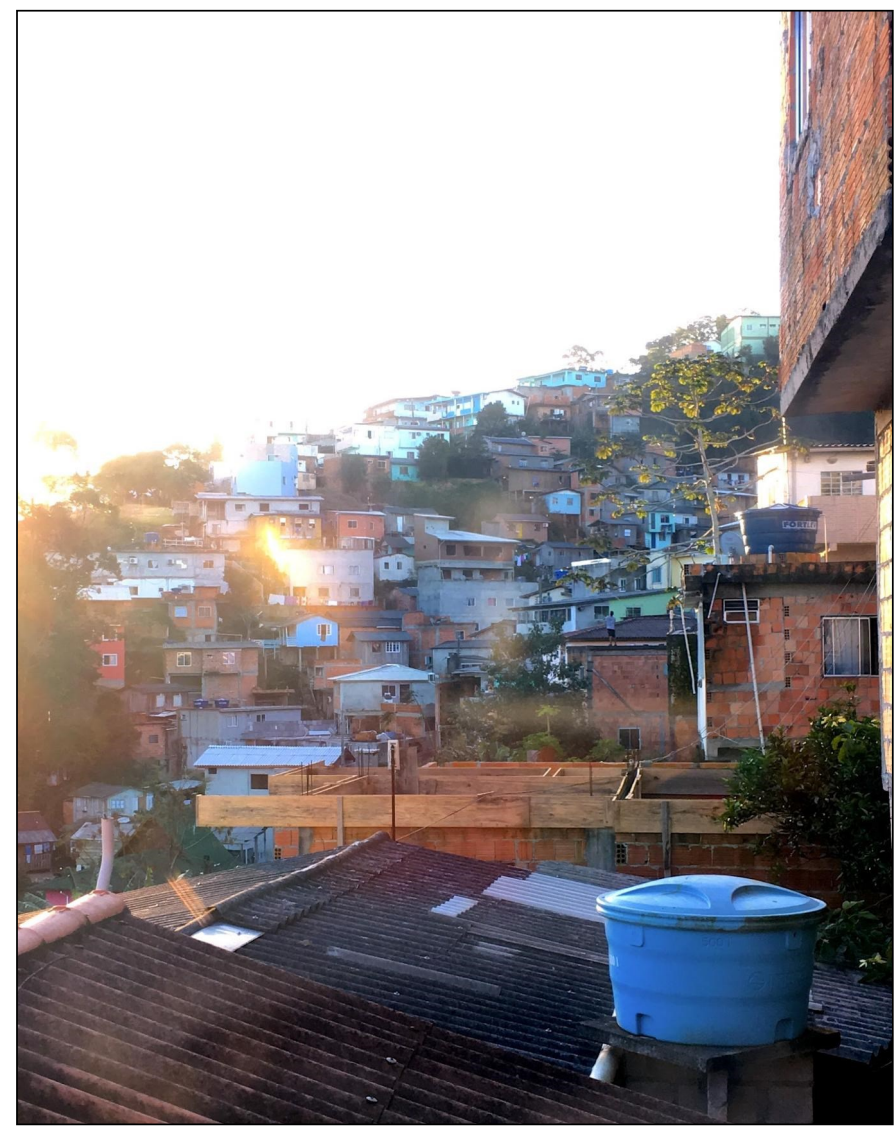

Figure 1: View from Serrinha of houses packed onto a hillside in a neighboring favela, Caeira. Photo by author, June 2019.

Brazilian scholar Beatriz Jaguaribe (2004) provides a succinct history of the favela:

The word favela designates the slum areas without basic sanitation and infrastructure that exist in almost all the cities of Brazil. The origins of the term favela began in the late nineteenth century when homeless soldiers returned from the backlands of Bahia after having exterminated the messianic rebel uprising of Canudos. While fighting in Canudos, the soldiers had camped on a hill covered by vegetation known as "favela."
Upon returning to Rio de Janeiro, the soldiers never received the promised government housing and built makeshift shacks on a hill near the centre of Rio. They named their location Favela in a clear reference to Canudos. According to the 2000 census undertaken by the IBGE, favela populations have increased throughout Brazil. In a city such as Rio de Janeiro, the favela population increases in one year what the urbanized city population increases in six. (339)

With the abolition of slavery and the intensification of rural to urban migration during the 1900s, migrants moved into cities (Perlman 2010, 26-8) where neither the landscapes nor governing bodies were prepared for the influx. Migrants with very few assets flooded the urban peripheries of central and southern Brazilian states, moving in where they had connections: "in many cases, new residents found people that had came [sic] from their same place of origin, and those networks provided some sort of initial support and opportunity" (Benmergui 2012, 45). In contrast, formal systems discriminate against periphery residents, who "face overt discrimination on the basis of their address, particularly if settlements are stigmatized by high levels of gun and/or drug crime, and are often unable to provide employers with a formal address because of the informal/illegal nature of their residence" (Grant 2010, 9). Favela residents, therefore, have costly and external barriers to entry into labor markets, leading to the cyclical geographic concentration of "socioeconomic and political exclusion on the basis of...identity" (9). This place-based identity is linked to other identities. For example, favelas are more or less synonymous with AfroBrazilians-in Rio de Janeiro, sixty percent of favela residents were recorded to belong to that racial identity (Saenz 2015). Therefore, though distinctions between a center and periphery are visible in every city's physical landscape, the processes that place and maintain the divisions between the two areas are human-made and social.

A wide range of ethnographies detail life in favelas and provide a way to contextualize Serrinha, the favela of interest in this study. Carolina Maria de Jesus' diary turned groundbreaking emic ethnography of life in a São Paulo favela 
adds detail to the favela experience. She notes general insecurities, violence, poverty, and drugs in her favela; however, she also describes interactions among neighbors that can be interpreted as strong adherence to the community despite these challenges (de Jesus 1962). Janice Perlman's (2010) highly regarded ethnographic work spanning over forty years of extensive research, Favela, is also critical for contextualizing favelas. Though Perlman notes what ethnographies like de Jesus's observe, she more importantly fights the "shock of the real" lens that the media has used to portray favelas. This refers to a concept that Jaguaribe (2005) has used to describe how the media has represented favelas through exhibiting violent occurrences as the quotidian. For example, the lens is employed in movies such as City of God, whose directors portray extreme and frequent drug-related crime in the favela. Perlman (2010), in contrast to popular portrayal, emphasizes the agency and optimism of favela residents within their "hostile environment" by displaying their talents and assets. She lays out the divisions within her favelas of study and counters the typical representation, even describing residents' attachment to their neighborhoods (235). The reality of everyday life in Serrinha certainly reflects many of the characteristics typical to favelas but, as Perlman's work suggests, it is also not onedimensional.

\section{Locating the Serrinha Favela}

Stark differences in city landscapes are not unique only to infamously unequal cities like Rio de Janeiro. Florianópolis, the capital of the southern Brazilian state of Santa Catarina, ranks as the third most developed city in Brazil (Atlas of Human Development 2010). Yet, the municipality is no exception from the presence of these informal, low-income favelas. In 2010,

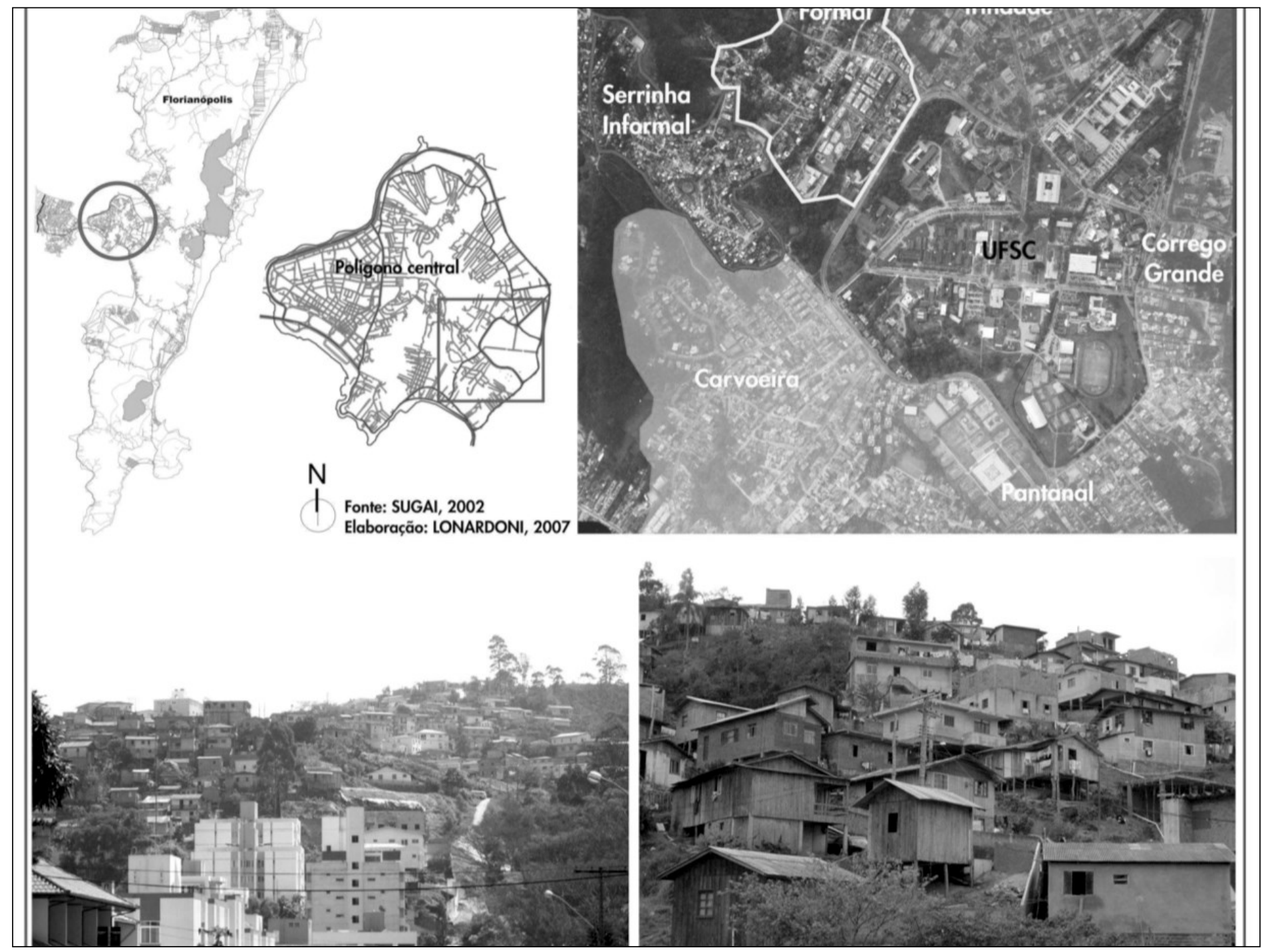

Figure 2: Greyscaled map and images depicting the location and make-up of Serrinha ("Serrinha Informal" in the top right map). Original source: Lonardoni 2007, 64. 
the Instituto Brasileiro de Geografia e Estatística census counted 421,240 citizens for the municipality of Florianópolis. A study in 2008 recorded around 51,600 Florianópolis citizens living in favela areas (Sampaio et al. 2013, 33) across 61 favelas throughout the municipality (Lonardoni 2007, 44), making the favela population over $12 \%$ of the total municipality population. Of this population, 37\% live in the Maciço Central do Morro da Cruz area, where Serrinha can be found. Geographically, Serrinha is located at the periphery of neighborhoods that are primarily associated with the Universidade Federal de Santa Catarina (UFSC) and its students (see Figure 2). Serrinha is interesting in that it is broken into a formal and informal section (Voltolini 2003, 42) (see top right of Figure 2). This simply means that there are legal homes and tall apartment complexes at the bottom of the steep hill near UFSC (Sampaio et al. 2013, 35); the higher one travels up the hill to enter informal Serrinha, the more precarious and autoconstructed the houses become (Sugai 2009, 170).

Serrinha's existence is rooted in waves of rural-urban migration to Florianópolis during the 1980s-migrants generally coming from the countryside of Santa Catarina and later from northeastern states such as Bahia (Inês, personal communication; Renata, personal communication). The poorest and blackest region in the nation (Chepkemoi 2017; IBGE $2015,12)$, the northeast is discriminated against in public rhetoric, with migrants from the area derogatorily labeled baianos (Carvalho and Fonseca 2018, 7). Serrinha was initially attractive to migrants due to its location in relation to the formal sector ( $\mathrm{O}$ Centro and UFSC neighborhoods) and its affordability (Lonardoni 2007, 71). However, as the community grew, so did social stigma surrounding it; in 1990, the military police invaded Serrinha with the intent to take down the self-constructed homes, but residents' physical protest stopped them (Lonardoni 2007, 78).

Today, the shortest way to get from O Centro to UFSC is by driving up one side of Maciço Central do Morro da Cruz, the hill upon which Serrinha sits, and down the other side on the main neighborhood road, the Transcaeira. Because of the Transcaeira and Serrinha's location, the area is served by the public bus system and is thus not completely cut out from that aspect of public services. However, though Serrinha residents may now use the bus system to travel into Trindade and O Centro, they do so to access basic necessities that are only available in the formal areas or their working class jobs in cleaning and manual labor (Lonardoni 2007, 78). Serrinha residents have criticized the road as "serving only as a connection between two important sides of the formal city....and in general only the population that does not reside in Serrinha" (translated from Sampaio et al. 2013, 46). This illustrates how patterns of "integration and exclusion" (Penglase 2008, 121) of neighborhoods are self-perpetuating and inseparable. Furthermore, it illustrates that Serrinha residents identify Serrinha as a place of exclusion, recognizing the distinction between their geographic and social position and the normative city.

\section{Methodology}

When I studied abroad at UFSC in 2018, I was aware of Serrinha, the favela closest to the university, but never interacted with the neighborhood. Wanting to analyze both the neighborhood and the social factors behind the separation between the formal city (places like UFSC) and informal peripheries, I returned in June and July 2019 to conduct research in Serrinha. My research employs ethnographic methods such as participant observation, semistructured interviews, and discourse analysis. To document my participant observation experiences in Serrinha, I took notes and photographs of public neighborhood spaces (see Figure 3). Additionally, I sketched a rough map of the space as I began experiencing it to provide more illustration (see Figure 4). These methods aid in capturing the emic perspective of place.

My first contact in the neighborhood was a newly-immigrated Serrinha resident around my age, Lourenço. My first significant observations took place as I tagged along with him. I eventually began volunteering in an important neighborhood NGO, Casa São José, an institution providing extra guidance for students during the hours of the day that school is not in session. There, I furthered my 
participation in the neighborhood; Casa São José allowed my entrance into the community's trust as I worked with neighborhood children and became known to parents through their kids. As I accompanied Lourenço in his daily life throughout the neighborhood and city, we met new participants for semi-structured interviews at various social sites. These sites varied and included places from a neighborhood thrift store, living rooms of participants, to on the street.

At these sites, I employed the method of snowball sampling to procure more participants. All participants were recruited voluntarily, and though not chosen based on demographic criteria such as race or gender, these markers were noted. Because I had lived in the formal neighborhood of Trindade with a family during my 2018 study abroad, I was also able to reach out and converse with my old host sister and mother, who helped vocalize the etic perspective-in this case, of non-Serrinha residents. Over the course of two months, I conducted fourteen semi-structured conversations in Portuguese with twenty participants ranging from twenty to sixty years of age and varying in race and gender. All were given pseudonyms to ensure confidentiality.

My questions for the interviews were built upon two separate community-asset research experiences, from which I took and adapted questions. I asked questions such as: What in your community are you proud of? Where is your favorite place in the neighborhood? In Florianópolis? Describe your relationship with your neighbors. I was attuned to how the respondents described physical infrastructure, social relations, and how they located Serrinha within the social and physical geography of the broader city. These types of questions not only

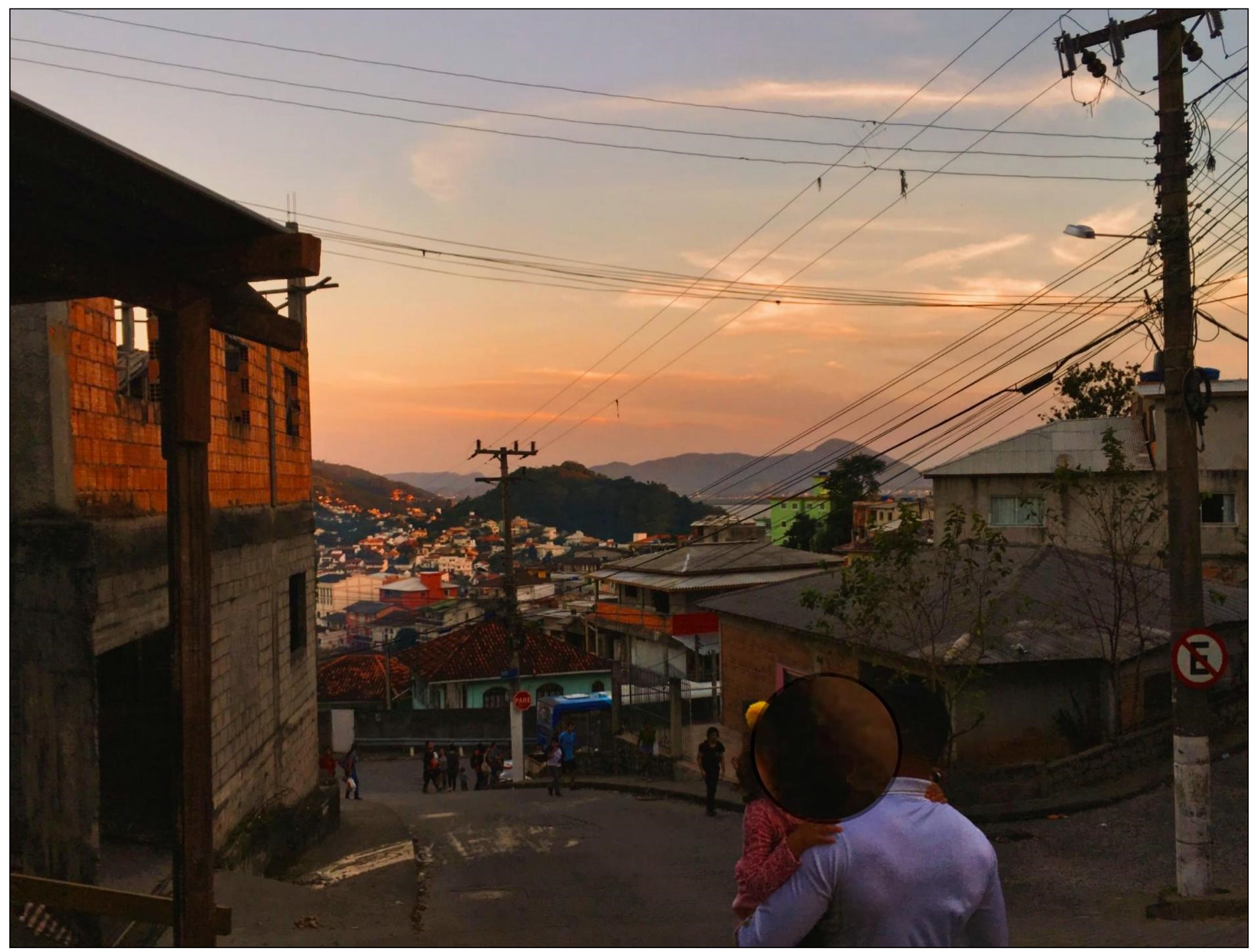

Figure 3: Sunset over the normative city, seen from the bend of Rua Marcus Aurélio Homem, the main road of Serrinha. Photo by author, June 2019. 


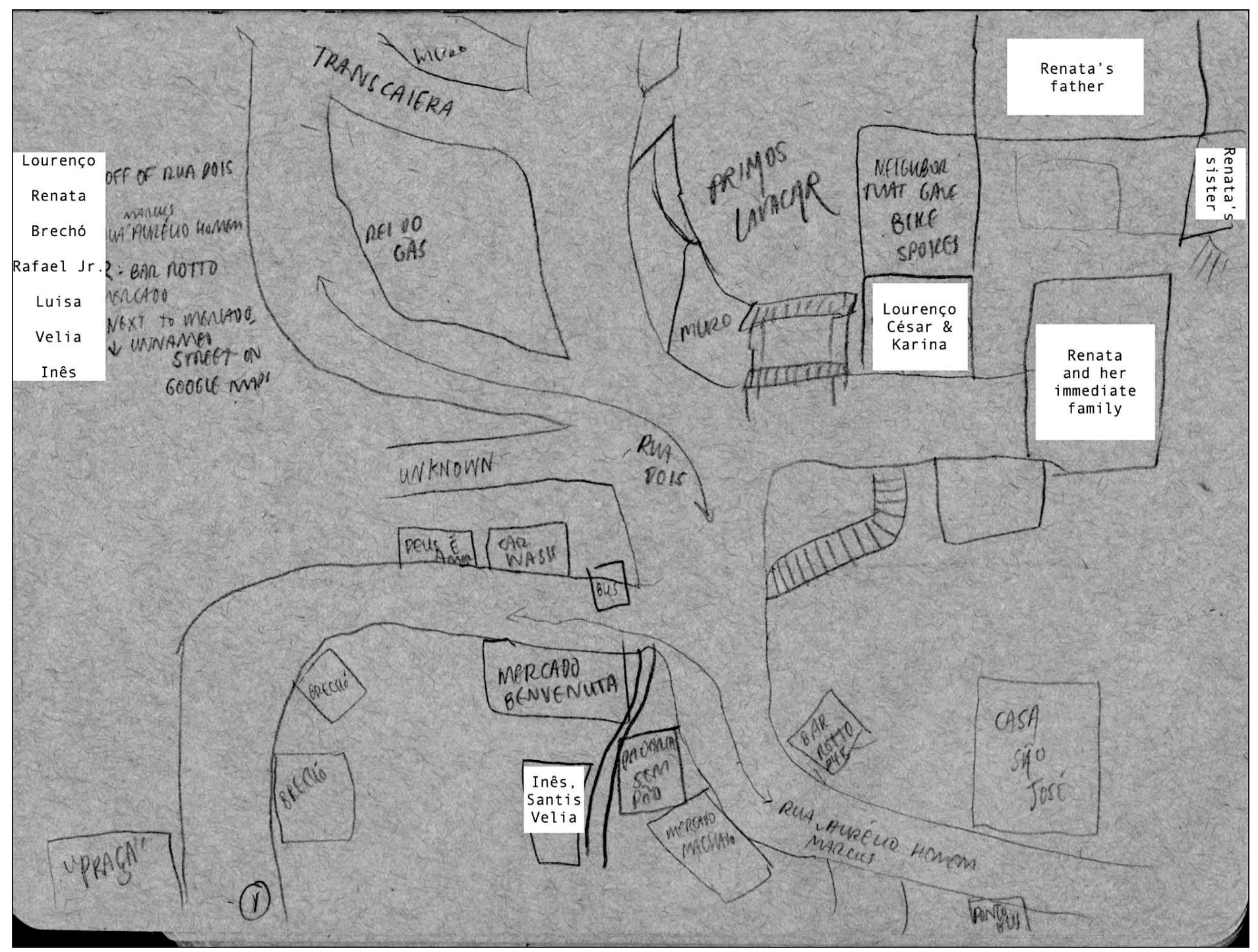

Figure 4: Rough, incomplete map created during first days of fieldwork. Location labels edited to protect participants' names. Map by author, June 2019.

encouraged answers about community identity, but also prompted informants to discuss the ways in which physical sites are constructed to reflect social realities. I used discourse analysis to examine responses and participants' implicit attitudes, for example, when interpreting why a participant may use non-derogatory terms to describe their circle within the neighborhood, but racially derogatory terms to describe other residents.

\section{Space, Place, and Related Concepts}

To explore the internalization of urban separations into place attachment, it is necessary to abstract the notion of space from that of place. This is done well in the field of urban anthropology, whose recent research trends have condensed around the "symbolic and social production studies of urban space" (Low 1996, 402) and theorizations of space and place (Low 2009, 22). Anthropologists Gupta and Ferguson (1997) delineate these notions of space and place:

By always foregrounding the spatial distribution of hierarchical power relations, we can better understand the processes whereby a space achieves a distinctive identity as a place. Keeping in mind that notions of locality or community refer both to a demarcated physical space and to clusters of interaction, we can see that the identity of a place emerges by the intersection of its specific involvement in a system of hierarchically organized spaces with its cultural construction as a community or locality. (36)

In other words, a place is artificially derived from a spatial landscape through social and cultural processes. This speaks to the 
anthropological concept of "representational cities," a term that argues that the built environment of the city is a text and history to be read (Low 1996, 386). The creation of places from space is never completely removable from deeper social meanings, processes, and networks (Forrest and Kearns 2001; Soja 1980), as demonstrated in scholars' exploration of urban favelas.

Urban anthropologists have created terms that further explore place. One such term is place attachment (Altman and Low 1992), which describes the emotional, "affective relationship" (Marzano 2015, 42) that people have to place. Social anthropologist Gilberto Marzano breaks down Scannell and Gifford's (2010) popular tripartite model of place attachment into three dimensions: "the actor dimension that represents who is attached...the psychological process through which affect, cognition and behavior occur in the attachment...[and] the object of the attachment, the place, including its social and physical characteristics" (Marzano 2015, 45). In Serrinha, I argue that the basis of place attachment is cemented in, based on, and related to the house and the brick that makes it. The process and reasoning behind physical construction, including choice of material, cannot be understood as another layer separate from the social, as it ultimately symbolizes the social. As residents build their experiences and relationships into their homes (a "psychological process"), the bricks and buildings (the "objects of attachment") become a synecdoche for the social and familial relations connected (the "actor dimension") to Serrinha and the houses.

Previous studies find that the social dimension is normally emphasized more heavily than the physical in the formation of place attachment (Hidalgo and Hernández 2001, 275). In their seminal work, Hidalgo and Hernández find that in this social aspect, the house is the most significant object or range of attachment (278); their findings differ from other works that have framed the neighborhood as the range of attachment that is most significant for place attachment (273). More research is needed to expand on Hidalgo and Hernández's findings to understand the "significant ranges for place attachment," as well as to address the "gap regarding...spatial environments...and

whether

the neighbourhood range is effectively the basic level of attachment, as many studies assume" (Hidalgo and Hernández 2001, 273). To contribute to this literature, I apply the anthropology of materiality to the Serrinha brick to assert that the basic level of attachment in Serrinha is the individual house rather than the neighborhood itself.

Of course, people attach personal sentiment to their homes in any neighborhood. Like Dona and Dafne, my old host mother and sister living in Trindade, who feel little connection to the neighborhood but much attachment to the modern apartment they have called home for over twenty years. What distinguishes selfmade Serrinha houses from apartments like theirs and gives them significance is that they are autoconstructed. Autoconstruction of homes can cause issues in internal and external relationships (namely legal ones), but also creates an object of attachment for residents that has a deep personal and social significance, especially in favelas such as Serrinha. My ethnographic findings walk through the typical Serrinha house, social networks, and how place attachment is formed in Serrinha. Ultimately, as residents build their homes on Serrinha soil, they ironically "ground the very social order that exploits them" (Holston 1991, 448) by finalizing, in a way, their attachment to and identification with the neighborhood.

\section{Findings}

\section{Family, House, and Metaphor}

The best understanding of belonging, social relations, and identity in Serrinha comes from analyzing the physical house. A participant in D'Avella's (2014) ethnography on the symbolism of bricks stated that "'a house, maybe sometimes it's going to be worth more, maybe sometimes it's going to be worth less, but it's yours"' (188). So, even over a theoretical US\$3M dollars, Rafael Junior's ownership and the cost he paid in sweat to build the house reigns dominant. His story shows us that in the end, a house is not a purely physical structure, but one built from intangible and non-fungible valuations.

A much clearer explanation begins by borrowing the words of anthropologist Kristin 
Skrabut (2018): houses "[materialize] domestic aspirations and kinship strategies" (271) and "are important relational resources that allow people to maintain ties across generations and accumulate extended kin" (278). Most of my interviewees testified to this either by word or through the example of their house. Ana, for example, moved from Saco de Limões (a middle -class, nicer neighborhood) to Serrinha when she got pregnant with Laura, her first child with Tiago. At that point, Ana and Tiago were not married. Though Tiago had grown up in Serrinha and Ana had not, she left everything to come live with him and start their immediate family.

She and Tiago moved into a small house and continued to build onto it. Perfectly metaphorical, the number of rooms in the house grew as the family did when Ana and Tiago added a child or welcomed extended kin to live with them. Ana described that her house has three bedrooms: one for her and Tiago and one for each of the two kids. Now, Serrinha's meaning for Ana is as "her neighborhood, her house, her place." They wanted to expand the house since their niece was living with them and they felt the need to grow, like Skrabut (2018) described happening in Peruvian lowincome areas. Now that Tiago and Ana have saved some money, they are planning to build a new unit on top of their current house and then rent out the bottom level where they currently live. The house will grow as their saved wealth increases, and Tiago and Ana will symbolically and literally move upwards. Tiago's dream is to save up enough money to buy a house in a middle-class neighborhood like Saco de Limões, where Ana lived, but will settle for improvements on their house within Serrinha in the meantime.

Nevertheless, it is not only familial kinship that is encompassed in the physical house, but also social networks in general. Giovanni is the godfather to Ana and Tiago's youngest child, and because he keyed into the house during the recorded interview and sat down in comfort, it was easy to tell he was close to the family. I asked how they all had met and how they entrusted Giovanni to be the godfather of their child. Ana simply responded that he lived a few houses away, so they had met and trusted him. He is now quite a part of their family-he eats meals and runs errands with the family and even takes naps in Ana and Tiago's living room-furthering the "kinship strategy" metaphor of houses. As Giovanni integrates himself into the physical house, he becomes a part of the family's safety netGiovanni takes care of the kids on occasion, even buying clothes and supplies for them. Ana and Tiago, by welcoming Giovanni into their house, have expanded their kinship network and have consequently obtained extra security for their children.

Many of my friends moved to Serrinha for a similar reason to Ana-family. Lourenço moved to Serrinha because César invited him to, and César moved in because his sister, Karina, had invited him to. Velia, Inês, and Luisa all married into families that had physical and social connections in Serrinha, so they moved into the neighborhood to be with their families. All the while, their families had been constructing and adding onto existing houses to accommodate them. In this sense, Velia and Inês' house is particularly interesting. Inês and Velia are sisters-in-law, married to a pair of brothers. Inês and her husband, Santi Senior, moved to the neighborhood before Velia, due to Santi Senior's connections in Serrinha. Inês and Santi Senior built their house and built Velia's right next to theirs as well, which today can be found next to Mercado Benvenuta (bottom left to center in Figure 4). Their home is "complete," with a cement layer over the raw brick that many other Serrinha houses never covered. The houses even have a gated, cemented outside area (though very narrow) that both separates them from the side street and unifies the two houses into one unit.

Movement between Velia and Inês' homes is completely fluid, especially due to this outside area and Velia's young children, who run in the tiny alley between the two houses screaming, weaving in and out of the rooms of the two houses, back and forth and back and forth. They force the households together. Velia uses this proximity as well. She often pops into Inês' living room looking to borrow kitchen supplies, which Inês always allows, never getting up since Velia comfortably navigates Inês' kitchen and takes what she needs. They are two sisters-inlaw and two brothers whose families are encompassed in two physical houses right next 
to each other, connected symbolically and physically into an extended family unit.

In the end, it is always about the house and the family, more so than the neighborhood. The house is the primary object of place attachment. Why would Rafael Junior not leave Serrinha? Because he "needs his family" and "has stability" in the neighborhood. I am not sure if he was speaking about stability in regards to family or his house, but in the end they are one and the same. Family, house, stability. Friendly Maura, who loves Serrinha equally as much as Rafael Junior, even to the point of defensiveness, would leave the community for personal house needs. She explains that her house is becoming too small; she wants to garden more but has no outside space, as her house is right next to Rua Marcus Aurélio Homem. Though Maura has lived in Serrinha since birth and has friends there that are like siblings, leaving the neighborhood would not upset her if it meant moving into a bigger house (Maura, personal communication). Ultimately, place attachment can manifest anywhere because it is rooted in the house rather than the neighborhood itself.

\section{On Knowing and Being Known}

Being raised in Ohio, I arrived to the Florianópolis winter armed with overconfidence in my ability to handle cold. After several nights spent shivering in my bed, I scoured Serrinha for a brechó (thrift shop) where I could buy a cheap sweatshirt. Always guided by luck, the three women I approached on the street happened to own a local brechó, a small, yellow cement building on the turn of Rua Marcus Aurélio Homem (see Figure 5). Upon describing my needs, the women directed me to a brechó owned by their friend next door and encouraged me to buy from Mona instead as her clothes were cheaper. Mona introduced herself, describing her relationship with Serrinha as I picked through her hoodies. Finding one that I liked, I pulled out my card to pay and Mona ushered me next door to use their card machine, leaving her other customers completely unattended and her shop door wide open. The card machine could not be found, and Mona turned to me with a smile and pushed my card away from her, telling me to come back another day to pay.

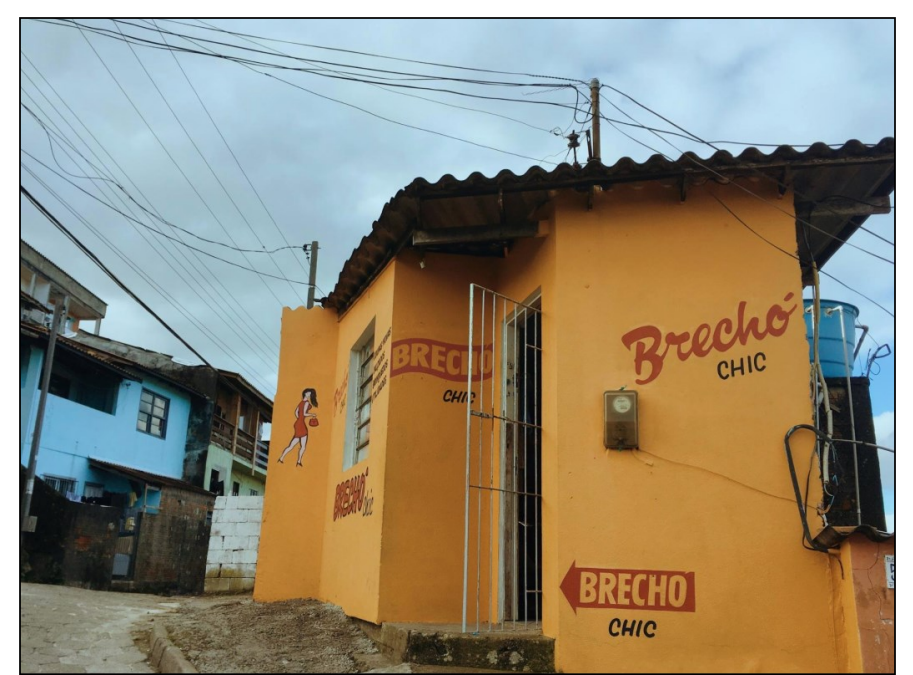

Figure 5: Bruna and Stefania's thrift store on the turn of Rua Marcus Aurélio Homem. Mona's is down the street to the right, not pictured. Photo by author, July 2019.

Not only did Bruna and Stefania unhesitatingly and non-competitively support Mona's business, but Mona extended a generous offer of trust to a stranger in addition to other customers. There was trust that I would return another day to pay for a good and trust of other residents in the neighborhood not to steal or wreck the store while unattended. This network of trust becomes daily habits that do not manifest as easily in other neighborhoods near UFSC. Of course, the informal nature of life in Serrinha is a possibility for the why, and this system of trust extends even to the most important issues within the neighborhood-land ownership.

Renata explained the process of selling and buying houses to me: in Serrinha, the ownership of land plots is implicitly known by most neighborhood residents, though it is often not legalized or recognized by the municipality. Therefore, the sale of a house in Serrinha or transfer of land ownership can generally only be notarized at most. With no real claim to land if ever there were to be a dispute over it, the transaction is valued at the level of trust between buyer and seller.

Economic anthropologist Bill Maurer (2006) explains this development: "states create value by the strength of their word and markets create value through substantial exchange" (27). In Serrinha's case, residents act as the state and as the market to create value. That is not to say that money or currency is not relevant, but in Serrinha, the non-money layer of exchange is most emphasized. In the absence of the 
normative state to validate, legalize, or back up transactions, something else must be offered up as assurance. Mauss speaks of this in The Gift with his theory of gift exchange, the idea that social implications and relationships are the impulse behind economic transactions. In Serrinha, one's social reputation, one's wellbeing, one's reward for years of investing in "becoming known" within the community are all put on the line as the collateral behind Serrinha contracts. This speaks to the lack of state protection within Serrinha and also accentuates the significance of one's social relationships in the set-up and maintenance of the neighborhood.

In Serrinha, knowing others is the greatest asset one could have. Your neighbors are literally family, you know everyone, you smile at the people you pass every day, and you extend that trust to others that are known in Serrinha, even if the recipient is a Korean-American girl. This begs the question: how do you become known within Serrinha? I became known as an extension of Lourenço, who is seen as a resident of Serrinha. A better question is how Lucas, the owner of a neighborhood market, became known. He does not live in Serrinha but in a nicer neighborhood called Agronômica, and people know this. Yet he can be seen at the market every day, working the cash register and making small talk with all customers that walk into the store on their way home. Though not a resident, he is effectively known and embraced in the community. Lucas also reflected that he feels safe and respected in Serrinha; after our interview, he even extended the goodwill of the
Serrinha community to me: "if you need anything, we are here."

Lucas owns a brick-and-mortar store that frames social interactions between him and Serrinha residents. People have attached Lucas's identity to the store and, since the store is in Serrinha, they transitively link Lucas to Serrinha and thus welcome him in the neighborhood. Present in this is the "psychological process" during which actors attach meaning and togetherness to another actor through an "object of attachment"-the store. Thus, in Serrinha, place attachment and the relationships people have or build are visible in physical buildings.

\section{The Brick as Metaphor}

For the two months that I stayed in Florianópolis in the summer of 2019, Renata and her family worked every single day on their house. The sounds of hammering, sawing, and men chattering filled the background of afternoons Lourenço and I spent cooking and eating in front of his house. Renata's house got bigger and bigger as we lazed around. Bricks were taken from the huge pile that had been transported to sit in the lot next to Lourenço's house and laid atop of each other precisely. Renata's house has the look of a complete, permanent favela home with cement over the brick; likewise, all the houses in formal neighborhoods have the brick covered in a layer of cement, though usually brighter and much neater. By the time I left, the additional floor was almost done, adding more space for Renata and her big family (see Figure 6)-

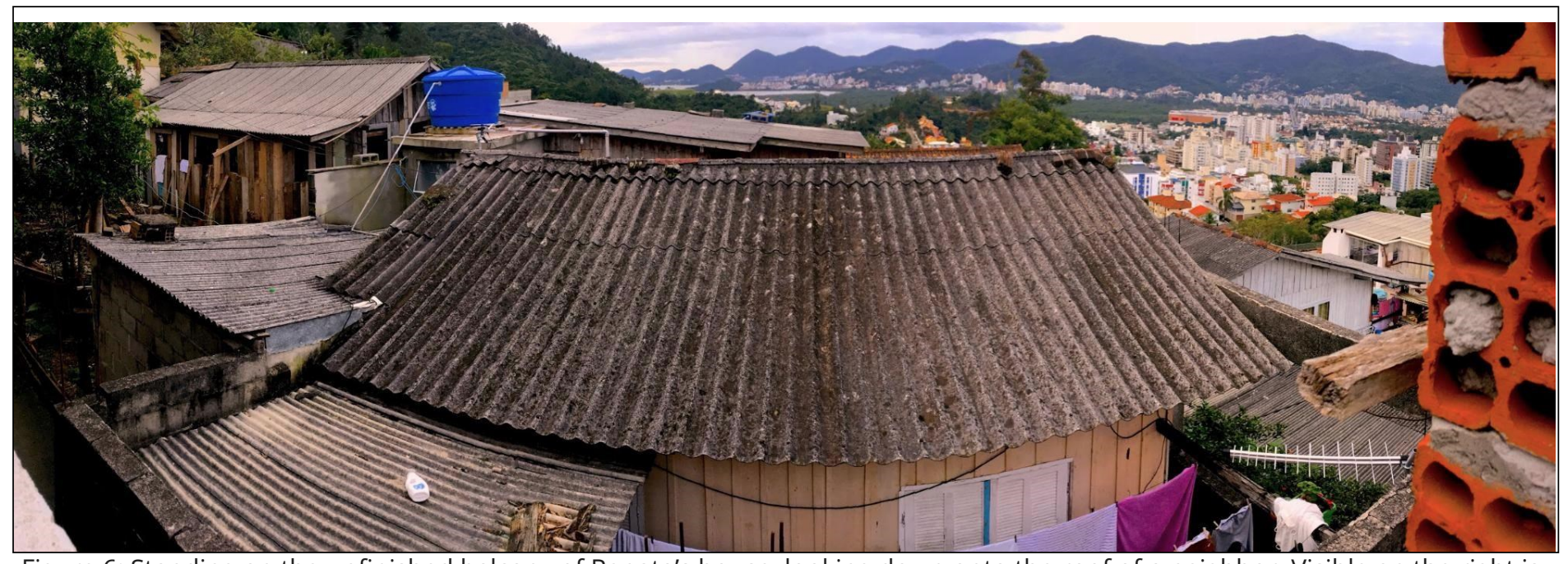

Figure 6: Standing on the unfinished balcony of Renata's house, looking down onto the roof of a neighbor. Visible on the right is the brick generally used in construction of houses. Photo by author, June 2019. 
downstairs, her self-owned thrift store and rooms for rent.

Renata was achieving the next step, so to speak, for her Serrinha house and social evolution. And she did it herself, or at least with only the help of her family. Laying each brick is both a physical and psychological process. Actors work and sweat to improve their houses not necessarily for a better view, but to regard themselves as better off than they were in the past. The brick signifies unlimited advancement and potential energy for expansion. If the three little pigs taught us anything, it is that brick is better than wood. In Serrinha, this could not be more true: brick means permanence and stability, and therefore more claim to Serrinha as part of one's identity. It is important that the house is autoconstructed, and it is more significant that the house is autoconstructed by brick.

When a brick house is put together, the constructed house is the becoming or manifestation of social and familial relations. "In the act of production" the Serrinha person that autoconstructs their house "couples his own movements and gestures-indeed, his very life-with the becoming of his materials, joining with and following the forces and flows that bring his work to fruition" (Ingold 2012, 435). Brick houses give the actor the ability to quite literally write their personal text. No brick is put down randomly, as theory within the anthropology of materiality suggests: "Human history has fundamentally to be understood as an ongoing process of objectification. In this, people create a material world that, in turn, provides a mirror in the reflection of which they and their successors fashion themselves" (Ingold 2012, 435). Hence, in Serrinha, why a house of brick? Brick is cheap, but sturdy. Brick can be bought and used in small increments, signifying the continuous process of autoconstruction. But what does the choice of brick mean (keeping in mind that the houses of newcomers, otherwise known as the "outsiders" or baianos, are autoconstructed from wood)?

Bricks connect discussions of the dynamism of materials to the symbolism of the physical Serrinha house. Anthropologist Tim Ingold (2012) explains the meaning of material:
To understand materials is to be able to tell their histories-of what they do and what happens to them when treated in particular ways-in the very practice of working with them. Materials do not exist as static entities with diagnostic attributes...'Matter is always already an ongoing historicity.' Materials, thus, carry on, undergoing continual modulation as they do so. In the phenomenal world, every material is a becoming. In this sense, we can agree with Deleuze and Guattari (2004) that materials evince a 'life proper to matter,' albeit one that is hidden or rendered unrecognizable by the terms of the hylomorphic model, which reduce matter to inert substance. (434)

Without actors to give meaning to brick, bricks are just inert blocks of clay and earth, as Ingold explained. However, even this is analogous. As earth, bricks are "lower cost" since there is "no shortage of raw material" (Frayssinet 2010); they are symbolically comparable to those who live in a favela, the class that provides no shortage of workers for lower-paying jobs. Made of clay and earth, there is a sense of rawness and humility in the material of bricks, especially when uncovered, as many Serrinha houses are. For a neighborhood that was created as its residents cut greenery and leveled ground, a neighborhood that ultimately has a complicated relationship with land and earth, bricks seem ironically fitting.

Employing this symbolic perspective, the brick in Serrinha must be seen as a metaphor for Serrinha. The brick is where the larger history, economic context, migratory movements, and invisible hierarchies that place people in Serrinha become tangible and actualized.

\section{Fragmented Community}

Only a few decades ago, Serrinha was covered with green bush, and remembering the days of green is a testament to one's belonging and pride. Remembering means one is an "original" or of the first wave that settled Serrinha, originating mainly from whiter southern states. Not being an original means one is either not a Serrinha resident or is an "outsider," someone who has migrated in from a northern state and is consequently seen as destructive, violent, and dirty by some originals (Renata, personal 
communication; Rafael Junior, personal communication; Tiago, personal communication). The clearest claim to being an original is in the location and material of the house. When one's house is made of brick and on the main road, it shows the roots one has in Serrinha and the meaning of the place to one's family. These are points that I have clarified in this article that demonstrate the connection between broader social relations, place attachment, and the house.

Serrinha is the actualization of racialized violence and larger hierarchies. One great illustration of this is Renata, who gatekeeps Serrinha-she refuses to rent her kitnets to baianos, or those who have an accent from the northeastern region, replicating global patterns of racial and economic exclusion and discrimination. Anthropologists Hann and Hart (2011) describe this: "The historical relationship between the peoples of rich and poor countries is one of movement in both directions....Keeping high- and low-wage labour streams apart through systematic racial discrimination has been elevated to a universal principle of world society, replicated at all levels more or less overtly" (118-9), which Renata unwittingly replicates in Serrinha.

The capitalist-motivated racism and movements-the slave trade from Africa into the north of Brazil- that have shaped the world economy are replicated from a global scale to the Brazilian scale, to the Florianópolis scale, and to the Serrinha scale. Migration from the northern parts of Brazil to the south is still common (again, many Serrinha residents come from Bahia), and these migrants generally end up in favelas like Serrinha within the city. Then, even within Serrinha, they face discrimination in finding housing and being wholly accepted into the community (as Renata's example shows), which can be interpreted as a replication of global processes. The outsiders live on the outskirts in houses made of wood planks (see Figure 7), whereas the originals live in brick houses and can even, in Renata's case, build rooms to rent at her discretion. So, Renata's identity resulting from being an original of Serrinha "built on territorial segmentation and regulation of movement across borders, justifies the unfair treatment of non-citizens and makes people blind to the common interests of humanity" (Hann and Hart 2011, 118). Through maintaining systems of discrimination and segregation that begin on a large scale and trickle down into the brick and wood of Serrinha houses, unification of the community is forgotten. In this way, brick is a metaphor for worldwide processes and hierarchies.

\section{Affection for the Place}

One of the walls of Renata's house is riddled with bullet holes, and an era of violence can be read or extrapolated from the physical state of the wall. But when Renata describes this wall, she speaks with an emphasis not on acts of violence, but with a sense of pride in and gratitude toward the house that successfully protected her and her family. She explains the exodus of residents that left during the "era of slaughter," and in this narrative is an implication of pride that she has stuck it out and stayed here at her roots. Like many other residents I interviewed, Renata cannot possibly imagine leaving the neighborhood. Luisa and Rafael Jr. want to raise their respective kids in the neighborhood, going so far as to turn down opportunities to move elsewhere. Even Inês, who does not always feel safe in Serrinha, says "[she] could never see herself living in another neighborhood."

The reasons Serrinha residents love the neighborhood and would not move away are socially based, as place attachment literature might suggest. There is comfort in friendship and in living right next to your whole family. Neighbors have been raised together since birth, and one is always recognized through an epithet of relation-Laura is known "not as Laura but as ahh, the daughter of Tiago"; Tiago is known by his childhood in Serrinha and his role in the Residents' Association. Not only familial relations but also old friendships guarantee one's survival and safety. People are able to knock on the doors of neighbors when they "need something, and [neighbors] are always ready to give...their friendship, something. Willingly" (Renata, personal communication). It is because of this that Rafael Jr. also loves Serrinha-“people here are very humble"-like the common Brazilian appellation of humble people for those that live in favelas might suggest. Stefania amalgamates 


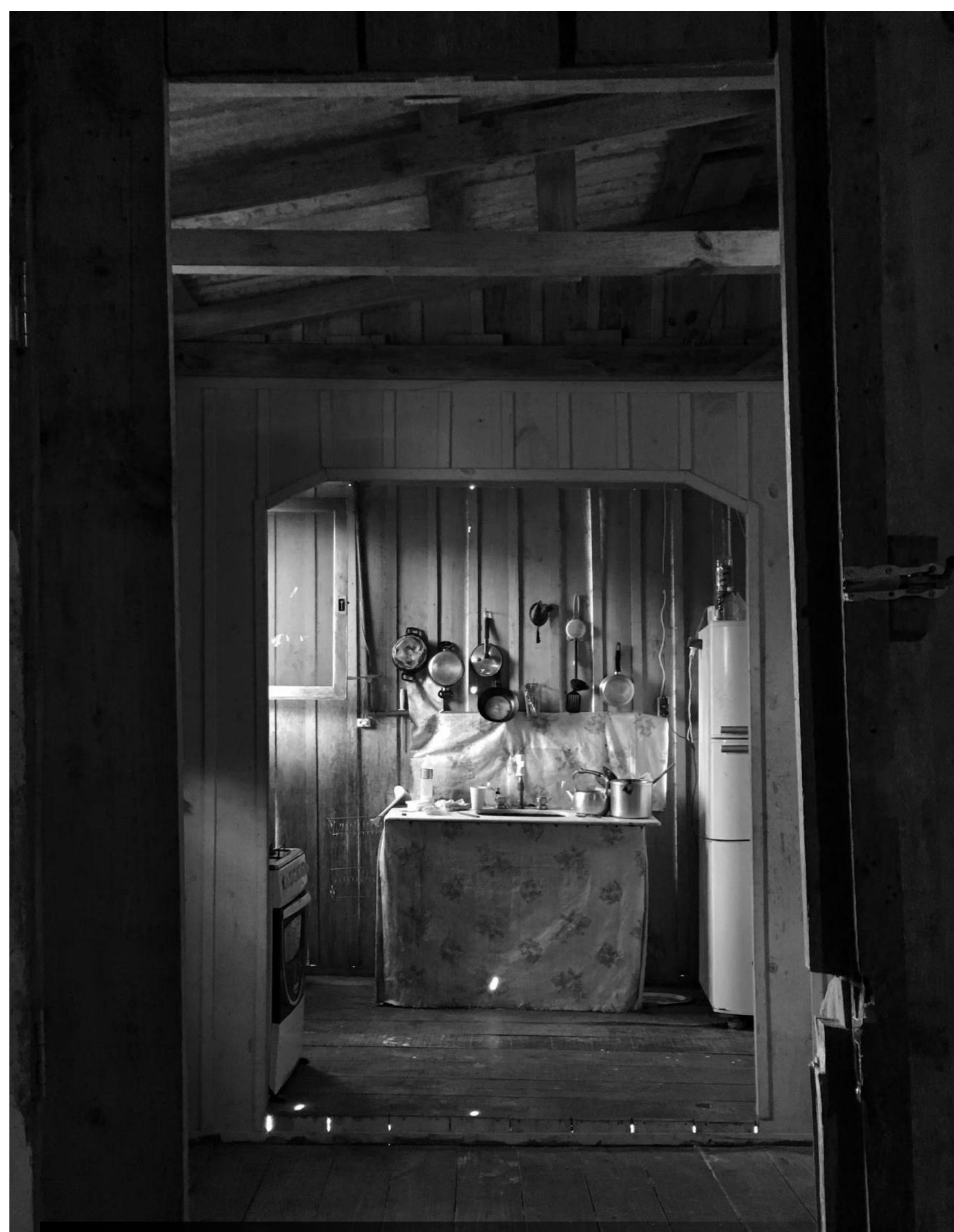

Figure 7: View of the kitchen in a self-constructed wooden Serrinha house on the outskirts of the community. Photo by author, June 2019. 
all these feelings for why she feels an attachment to the community: "it's as if it were a family."

In stark contrast is the experience of living in a formal neighborhood. Neither Dona nor Dafne go beyond the basic wave-and-greet for those even living on the same floor of their apartment in Trindade. Dona, Dafne, and their neighbors use their homes as a source of isolation and boundaries, quickly keying in after hellos and shutting their front doors. In Serrinha, hangouts bleed into the street and people move effortlessly in a flow of talk, moving from street to bar, bar to house, house to street. Always encompassed by the physical frame of a home or building, Serrinha residents interact and build affection to one another, welcomingly leaving their doors open for friends and neighbors.

\section{Conclusion}

After creation, Serrinha stayed divided from the formal city of Florianópolis through complicated social relations. Generally, tools like stigma and hyper-shocking media have created a negative image of favelas like Serrinha. But, though there are typical favela markers within the community, residents of Serrinha largely like Serrinha. Most participants mentioned their connections to friends, family, and their home as the basis for this liking and for their connection to the neighborhood. It is important to explore these elements of place attachment present in Serrinha, as it facilitates the use of a lens different than the typical, one that neither fully romanticizes Serrinha nor paints Serrinha as a shock of the real place.

In agreement with the trends in past literature illustrated by Hidalgo and Hernández (2001), the social dimension in Serrinha is emphasized more directly than the physical in the neighborhood's place attachment, since most participants overwhelmingly noted varying kinship relationships in their comprehension of Serrinha. Being known and utilizing the value that comes from it is an essential component of living in Serrinha. Residents use these social strategies and build them into their homes, developing their networks and their affection for place. These networks are made into text by the writing of one's house and family story in brick, so the physical and social dimensions of attachment are inextricably linked.

As noted earlier, bricks and their permanence consummate and "ground the very social order that exploits" (Holston 1991, 448) the Serrinha resident. In the act of laying bricks for their home, residents unwittingly accept these forces and become a part of these greater patterns of exploitation by solidifying their presence in and identity with the periphery, especially by autoconstructing their house, which further entrenches Serrinha in the favela category. The brick is the physical manifestation and foundation of all place and place attachment, literally and metaphorically. As the notion of autoconstruction indicates, the ongoing, continual becoming of the neighborhood is like "the globe itself...an invention...its reality is under construction" (Latour 2004 as cited in D'Avella $2014,175)$. Interpreting the physical make-up of the houses in Serrinha is to also understand the social stories of the neighborhood, like familial or kinship relations between owners of houses (D'Avella 2014, 175), which would otherwise be invisible unless talking to home owners-recall the gated front yard of Velia and Inês, who we would not know were related simply by walking past their homes. Likewise, D'Avella (2014) argues that material ceases to have meaning without "their relations... with those who have them" (175). This is the case for Renata's bullet wall, which takes life as a protector and source of safety, and evidences a time of dueling drug factions that has no written history.

Autoconstruction is crucial in Serrinha, as it is in most favelas. It signifies the psychological process from the tripartite model, as building a house becomes the process through which actors attach affection to an object. The insight provided by autoconstruction is that the house is a direct metaphor for the family and is deeply personalized; therefore, it should be expected that residents attach extreme significance to their home. Home is much more significant than the neighborhood in Serrinha. My research clarifies, as Hidalgo and Hernández (2001) do, that much more research is needed that focuses on the house as the range of attachment and the psychological processes that guide this. Moreover, more research that 
draws on material analysis is necessary, as it encourages deeper analysis of the relationship between the social and physical and gives insight into the unsaid during ethnographic fieldwork. When I noted discriminatory beliefs during my fieldwork and interviews, I could never bring myself to ask a participant if they thought they were racist, though this division is a significant aspect of the Serrinha story. Hence, I asked myself: Why brick? Why wood? And a narrative emerged from these questions. This emphasizes the potential of ethnography for exploring favelas and other peripheral areas. Using the ethnographic method to gain more nuanced knowledge is invaluable, as it can give us creative methods, such as material analysis, to understand the unsaid in periphery communities around the world. 


\section{Acknowledgements}

For making this research possible, I would like to extend my gratitude to my big, welcoming family in Florianópolis and to the Honors Tutorial College at Ohio University. Of the HTC family, I would especially like to thank my advisor, Dr. Smoki Musaraj, for being an invaluable mentor throughout the years. This research was actualized only through her encouragement, patience, and editing skills. 


\section{References}

Altman, Irwin, and Setha M. Low. 1992. "Place Attachment." In Place Attachment, edited by Irwin Altman and Setha M. Low, 1-12. Boston: Springer.

Atlas of Human Development. "Florianópolis, SC. " The Atlas Brazil. Accessed April 19, 2019. http://atlasbrasil.org.br/2013/en/ perfil_m/florianopolis_sc/\#idh.

Benmergui, Leandro D. 2012. "Housing Development: Housing Policy, Slums, and Squatter Settlements in Rio de Janeiro, Brazil and Buenos Aires, Argentina, 1948-1973." PhD diss., University of Maryland.

Caldeira, Teresa P.R. 2012. "Imprinting and Moving Around: New Visibilities and Configurations of Public Space in São Paulo." Public Culture 24 (2 (67)): 385-419.

Carvalho, Carlos Alberto, and Maria Gislene Carvalho Fonseca. 2018. "Between Forged Memory and Place Of Memory: São Cristóvão's Fair and Tradition." Contracampo 37 (3): 45-64.

Chepkemoi, Joyce. 2017. "The Richest and Poorest States of Brazil." WorldAtlas. https://www.worldatlas.com/articles/the-richest-andpoorest-states-of-brazil.html.

D'Avella, Nicholas. 2014. "Ecologies of Investment: Crisis Histories and Brick Futures in Argentina." Cultural Anthropology 29 (1): 173 $-199$.

de Jesus, Carolina Maria. 1962. Child of the Dark. New York: EP Dutton.

Forrest, Ray, and Ade Kearns. 2001. "Social Cohesion, Social Capital and the Neighbourhood." Urban Studies 38 (12): 2125-2143.

Frayssinet, Fabiana. 2010. "Bricks in Brazil- Eco-Friendly, Low-Cost and Cool." Inter Press Service: News Agency. http:// www.ipsnews.net/2010/07/bricks-in-brazil-eco-friendly-low-costand-cool/.

Grant, Ursula. 2010. "Spatial Inequality and Urban Poverty Traps." Overseas Development Institute, London.

Gupta, Akhil, and James Ferguson, eds. 1997. Culture, Power, Place: Explorations in Critical Anthropology. Durham and London: Duke University Press. 
Hann, Chris, and Keith Hart. 2011. Economic Anthropology: History, Ethnography, Critique. Cambridge and Malden: Polity Press.

Hidalgo, M. Carmen, and Bernardo Hernández. 2001. "Place Attachment: Conceptual and Empirical Questions." Journal of Environmental Psychology 21 (3): 273-281.

Holston, James. 1991. "Autoconstruction in Working-Class Brazil." Cultural Anthropology 6 (4): 447-465.

IBGE. 2015. "Síntese de Indicadores Sociais: Uma Análise das Condições de Vida da População Brasileira." Instituto Brasileiro de Geografia e Estatística, Rio de Janeiro.

Ingold, Tim. 2012. "Toward an Ecology of Materials." Annual Review of Anthropology 41: 427-442.

Jaguaribe, Beatriz. 2004. "Favelas and the Aesthetics of Realism: Representations in Film and Literature." Journal of Latin American Cultural Studies 13 (3): 327-342.

-_- 2005. "The Shock of the Real: Realist Aesthetics in the Media and the Urban Experience." Space and Culture 8 (1): 66-82.

Lonardoni, Fernanda Maria. 2007. "Aluguel, Informalidade e Pobreza: O Acesso à Moradia em Florianópolis." Master's thesis, Universidade Federal de Santa Catarina.

Low, Setha M. 1996. "The Anthropology of Cities: Imagining and Theorizing the City." Annual Review of Anthropology 25 (1): 383409.

-__. 2009 "Towards an Anthropological Theory of Space and Place." Semiotica 175: 21-37.

Marzano, Gilberto, and Ecoistituto del Friuli Venezia Giulia. 2015. "Place Attachment and Place Identity: Their Contribution to Place Branding." Culture and Creativity 41: 41-53.

Maurer, Bill. 2006. "The Anthropology of Money." Annual Review of Anthropology 35: 15-36.

Mauss, Marcel. 2002. The Gift: The Form and Reason for Exchange in Archaic Societies. London and New York: Routledge.

Penglase, Ben. 2008. "The Bastard Child of the Dictatorship: The Comando Vermelho and the Birth of 'Narco-culture' in Rio de Janeiro." Luso-Brazilian Review 45 (1): 118-145. 
Pequeno, Renato. 2008. "Políticas Habitacionais, Favelização e Desigualdades Sócio-Espaciais nas Cidades Brasileiras: Transformações e Tendências." Scripta Nova: Revista Electrónica de Geografía y Ciencias Sociales 12.

Perlman, Janice. 2010. Favela: Four Decades of Living on the Edge in Rio de Janeiro. New York: Oxford University Press.

Saenz, Sergio. 2015. "Statistics Reveal Alarming Rate of Police Violence in Rio." RioOnWatch. https://www.rioonwatch.org/? $p=21350$.

Sampaio, Adriana de Lima, Larissa Miranda Heinisch, Lucas Gustavo Anghinoni, Mariana Morais Luiz, and Adriana Marques Rosseto. 2013. "A Territorialidade das Cidades Informais: Estudo Relacional na Serrinha." PET Arquitetura e Urbanismo UFSC, Florianópolis.

Scannell, Leila, and Robert Gifford. 2010. "Defining Place Attachment: A Tripartite Organizing Framework." Journal of Environmental Psychology30 (1): 1-10.

Skrabut, Kristin. 2018. "Housing the Contingent Life Course: Domestic Aspiration and Extreme Poverty in Peruvian Shantytowns." City \& Society 30(2): 263-288.

Soja, Edward W. 1980. "The Socio-Spatial Dialectic." Annals of the Association of American Geographers 70 (2): 207-225.

Sugai, Maria I. 2009. "Há Favelas e Pobreza na 'llha da Magia'?" In Favela e Mercado Informal: A Nova Porta de Entrada dos Pobres Nas Cidades Brasileiras, edited by Pedro Abramo, 162-199. Porto Alegre: ANTAC.

Voltolini, Maurina. 2003. “Rede de Apoio Sócio-Comunitária-Uma Experiência Vivenciada na Comunidade da Serrinha, Florianópolis, SC." Bachelor's thesis, Universidade Federal de Santa Catarina. 